\title{
PENGEMBANGAN PERANGKAT PEMBELAJARAN MODEL INKUIRI MELALUI DROSOPHILA VIRTUAL LABORATORY PADA PEMBELAJARAN BIOLOGI SMA MATERI POKOK POLA-POLA HUKUM MENDEL
}

\author{
Marceline Prophylia ${ }^{1}$ \\ Soeparman Kardi ${ }^{2}$ \\ Wahono Widodo ${ }^{2}$ \\ ${ }^{1}$ Program Pascasarjana Pendidikan Sains Universitas Negeri Surabaya \\ ${ }^{2}$ Dosen Program Pascasarjana Pendidikan Sains Universitas Negeri Surabaya \\ email: mprophylia@yahoo.com
}

\begin{abstract}
This research is a study of the Development of Teaching and Learning Materials based on Inquiry Model through the Drosophila Virtual Laboratory in an Effort to Improve Student Learning Outcomes in Biology at Senior High School on Topic Learning Patterns of Mendelian Law. The subject of this research is Teaching and Learning Materials. Based on the validator's result the whole device is worth and can be applied. Based on the results of the application in the field, it appears that fulfillment of the lesson plan takes place very well. Student activity reaches $100 \%$ meaning that all students are active. Completeness results of the study of the students show a very significant change, the average score is 85 , which means all students complete the study. From the response of the students, generally they can accept/agree the learning tool developed by inquiry model through Virtual Drosophila Labs. It is an effective and innovative device that can make students more active, help them in improving their learning outcomes of the aspect of the spiritual, social, knowledge, and skills. Based on the results of the study can be concluded that the teaching and learning materials developed in this research is feasible and can be applied to improve student learning outcomes in biology at senior high school on topic learning patterns of Mendelian Law.
\end{abstract}

Key words: improved learning results, inquiry model, Drosophila Virtual Laboratory.

Abstrak: Penelitian ini adalah penelitian pengembangan perangkat pembelajaran Biologi SMA dengan model inkuiri melalui Drosophila Virtual Laboratory pada Materi Pokok Pola-pola Hukum Mendel. Subyek penelitian ini adalah perangkat pembelajaran. Berdasarkan hasil validasi seluruh perangkat dikategorikan baik dan layak diimplementasikan. Berdasarkan hasil penerapan di lapangan tampak bahwa RPP terlaksana dengan baik. Aktivitas siswa mencapai 100\%, yang artinya seluruh siswa bersifat aktif. Ketuntasan hasil belajar siswa menunjukan perubahan yang sangat signifikan, yaitu skor rata-rata 85 yang berarti seluruh siswa tuntas. Dari sisi respon siswa, secara umum mereka dapat menerima/setuju bahwa perangkat pembelajaran yang dikembangkan dengan model inkuiri melalui Virtual Drosophila Labs merupakan perangkat yang efektif dan inovatif, dapat membuat siswa lebih aktif, membantu dalam meningkatkan hasil belajar siswa dari aspek spiritual, sosial, pengetahuan, dan ketrampilan. Berdasarkan hasil penelitian ini dapat disimpulkan bahwa perangkat pembelajaran yang dikembangkan dalam penelitian ini berkategori layak dan dapat diterapkan untuk meningkatkan hasil belajar siswa pada pembelajaran Biologi SMA materi pokok pola-pola Hukum Mendel.

Kata Kunci : peningkatan hasil belajar, inkuiri, Drosophila Virtual Laboratory.

\section{PENDAHULUAN}

Berdasarkan Internet World Statistics, penduduk Indonesia di akhir tahun 2011 tercatat sebagai pengguna internet nomor 4 di Asia dan nomor 8 dunia. Dengan internet, pengetahuan semakin mudah dan murahnya, namun tantangannya adalah: apakah peluang itu dapat dimanfaatkan, khususnya di dunia pendidikan?

Pembelajaran melalui penggunaan teknologi (termasuk internet) juga telah dituangkan ke dalam UU Nomor 20/2003 tentang Sisdiknas: (3) Kurikulum disusun sesuai dengan jenjang pendidikan dalam kerangka Negara Kesatuan Republik Indonesia dengan memperhatikan: .... g. perkembangan ilmu pengetahuan, teknologi, dan seni;..." Dengan demikian, e-education, e-library, e-learning, e-journal, bahkan virtual university, cyber university, tele education, distance learning, dan virtual laboratory telah menjadi bagian dari proses pembelajaran terkini.
Pemanfaatan media pembelajaran berbasis TIK pun telah mengubah orientasi metoda pembelajaran dari teacher oriented menuju student-centered learning, termasuk dalam pembelajaran biologi. Dengan memanfaatkan TIK para siswa biologi harus lebih banyak mencari tahu (inquiry) tentang alam secara sistematis. Oleh sebab itu, penggunaan perangkat pembelajaran berbasis teknologi oleh siswa turut mendukung proses penemuan dalam pelajaran biologi, termasuk dalam topik Genetika materi pokok pola-pola Hukum Mendel.

Para siswa di SMA Santa Maria Surabaya, menurut pengalaman peneliti, mengalami kesulitan pada saat mereka belajar topik pelajaran Genetika KD. 3.4 yaitu "Menerapkan prinsip hereditas dalam mekanisme pewarisan sifat". pencapaian nilai Biologi pada materi pokok Hukum Mendel secara umum kurang memuaskan, saat para siswa mengerjakan ulangan harian pada 
semester ganjil 2013. Dari tiga kelas siswa kelas XII IPA, nilai pola-pola Hukum Mendel pada ulangan harian 1 hanya mencapai rata-rata 63 , di bawah KKM yang sudah ditentukan yaitu 75. Rata-rata ketuntasan klasikal dari tiga kelas pun hanya $50 \%$, di bawah seharusnya, yaitu $85 \%$. Hal tersebut disebabkan tidak adanya fasilitas praktikum, alat, serta bahan di sekolah untuk mengumpulkan, menganalisis data, dan melakukan uji coba genetika. Kalaupun ada, saat ini untuk mempelajari pewarisan sifat hanya menggunakan media kancing genetika. Untuk itulah diperlukan sebuah media pembelajaran virtual laboratory agar pola-pola Mendel yang diajarkan dapat lebih mudah diterima. Virtual Laboratory (laboratorium virtual dan disingkat virtual labs) adalah e-learning berupa simulasi dan visualisasi. Dalam virtual labs siswa memperoleh pengalaman praktis, misalnya dalam bentuk tiga dimensi dan materi interaktif secara virtual. Virtual labs menggunakan model-model komputerisasi dan bermacam-macam teknologi instruksional untuk menggantikan kegiatan tatap muka di laboratorium (Scheckler, 2003). Laboratorium virtual yang dapat membantu pembelajaran genetika dan digunakan dalam penelitian ini adalah Drosophila Virtual Laboratory atau Drosophila Virtual Labs. Laboratorium virtual tersebut adalah sebuah proyek dari The Virtual Courseware Project for Inquirybased Science Education (VCISE), yang didanai oleh U.S. National Science Foundation and the California State University, yang beralamatkan di http://www.science-courseware.org/vcise/drosophila. Laboratorium virtual tersebut ternyata efektif digunakan di Turki ( Cakir dan Karaagac, 2012).

Perangkat pembelajaran adalah sekumpulan pedoman pembelajaran yang memungkinkan guru dan siswa melakukan kegiatan belajar mengajar yang terdiri dari: Silabus, Rencana Pelaksanaan Pembelajaran (RPP), Buku Ajar Siswa, Lembar Kegiatan Siswa (LKS), Lembar Pengamatan, dan Lembar Penilaian Hasil Belajar Siswa yang meliputi aspek spiritual, sosial, pengetahuan dan keterampilan. Peneliti menggunakan model inkuiri dengan mengacu pada teori konstruktivistik dimana siswa melakukan suatu proses untuk menjawab pertanyaan dan memecahkan masalah berdasarkan fakta dan observasi, sedangkan peran guru bukan sebagai pemberi informasi melainkan sebagai fasilitator (Kardi, 2013). Dengan demikian, yang menjadi pusat proses pembelajaran model inkuiri adalah siswa (Ibrahim, 2007).

Atas dasar hal tersebut maka "Bagaimanakah kelayakan perangkat pembelajaran yang dikembang-kan dengan Model Inkuiri melalui Drosophila Virtual Laboratory dalam meningkatkan hasil belajar siswa pada pembelajaran Biologi SMA pada Materi Pokok Polapola Hukum Mendel?"

\section{METODE}

Penelitian ini adalah penelitian pengembangan perangkat pembelajaran untuk menghasilkan perangkat pembelajaran tingkat SMA dalam pelajaran biologi dengan materi pokok Pola-pola Hukum Mendel dengan model pembelajaran inkuiri melalui Drosophila Virtual Laboratory. Setelah itu, peneliti mengimplementasikan perangkat yang dikembangkan tersebut dalam uji coba untuk mengetahui tingkat kelayakannya. Sasaran penelitian berupa Silabus, Rencana Pelaksanaan Pembelajaran (RPP), Lembar Kerja Siswa (LKS), Bahan Ajar Siswa (BAS) dan Lembar Penilaian tersebut dikembangkan dan diujicobakan pada 30 siswa kelas XI IPA tahun pelajaran 2013-2014 SMA St. Maria Surabaya.

Prosedur penelitian dalam pengembangan perangkat pembelajaran ini menggunakan modifikasi model yang dikembangkan oleh Dick dan Carey (2005, dalam Pribadi, 2011)

Penelitian ini terdiri dari dua tahap, yaitu tahap pertama perencanaan penyusunan perangkat pembelajaran yang didasarkan pada Drosophila Virtual Laboratory melalui pendekatan saintifik-inkuiri, dan tahap kedua adalah implementasi perangkat pembelajaran di kelas. Penyusunan perangkat pembelajaran meliputi Silabus, RPP, lembar penilaian yang meliputi aspek spiritual, aspek sosial, aspek pengetahuan dan aspek keterampilan. Tahap implementasi perangkat pembelajaran melalui 2 tahap, yaitu tahap uji coba dan pelaksanaan penelitian.

Uji coba perangkat pebelajaran ini menggunakan rancangan one group pretest-posttest design dari Tuckman (1978), dengan gambaran sebagai berikut :

Dimana;

\begin{tabular}{|lll|}
\hline O1 & X & O2 \\
\hline
\end{tabular}

$\mathrm{O} 1=$ uji awal

$\mathrm{X}=$ implementasi perangkat pembelajaran berbasis

$\mathrm{O} 2=$ uji akhir

Untuk mengetahui tanggapan siswa terhadap terhadap pembelajaran yang digunakan maka akan diberikan lembar angket yang akan diisi oleh siswa.

\section{HASIL DAN PEMBAHASAN}

Analisis data penelitian dilakukan secara deskriptif kualitatif dan kuantitatif sesuai dengan kriterianya. Hasil pengembangan perangkat berupa silabus, RPP, lembar kerja siswa dan buku ajar siswa serta lembar penilaian dan pelaksanaan pembelajaran di kelas dengan perangkat pembalajaran model inkuiri 
melalui Drosophila Virtual Laboratory pada topik polapola Hukum Mendel divalidasi dosen dan pakar genetika. Secara lengkap pembahasan adalah sebagai berikut:

Hasil validasi silabus dan RPP oleh tim validator mendapatkan skor dengan kategori baik, sehingga silabus dan RPP yang telah dikembangkan peneliti dapat dikategorikan layak digunakan untuk pembelajaran materi pokok pola-pola Hukum Mendel.

Berdasarkan hasil validasi para validator, LKS yang dikembangkan peneliti untuk aspek format mendapat skor 3.5 (kategori cukup baik dan dapat digunakan dengan revisi kecil); aspek isi mendapat skor 3.6 (kategori baik dan dapat dilaksanakan tanpa revisi); sedangkan dari aspek bahasa mendapat skor 3.4 (kategori cukup baik dan dapat digunakan dengan revisi kecil). Dengan demikian, secara keseluruhan LKS dapat dikategorikan baik dan layak digunakan.

Buku ajar yang telah dikembangkan pun telah divalidasi oleh validator dan memperoleh skor rata-rata 3.6 sehingga dapat dikategorikan baik dan layak dipergunakan. Secara keseluruhan, hasil validasi Lembar Penilaian berdasarkan komponen materi, konstruksi, dan bahasa lembar penilaian, para validator memberikan ratarata skor 3.8 dengan kategori baik dan layak dipergunakan.

Keterlaksanaan tahap-tahap pembelajaran yang dilakukan peneliti pada pertemuan pertama, kedua, dan ketiga adalah terlaksana $100 \%$ dengan skor keterlaksanaan dari masing masing tahap mendapat nilai rata-rata dengan kategori baik dan nilai rata-rata reliabilitas untuk tiga kali pertemuan $87.7 \%$, dimana para pengamat memberikan nilai rata-rata $3.82-4.00$, seperti tampak pada Gambar 1.

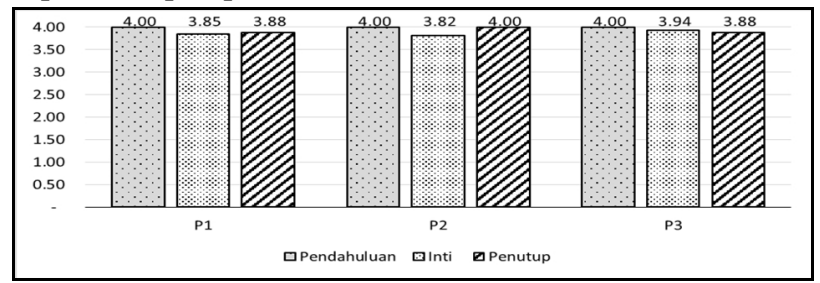

\section{Gambar 1. Grafik Pengamatan Keterlaksanaan RPP}

Dalam hal ini bisa diasumsikan bahwa instrumen yang digunakan masih reliabel. Instrumen keterlaksanaan RPP dikatakan reliabel, apabila reliabilitasnya $\geq 75 \%$ (Borich, 1994 dalam Ibrahim, 2005). Hal ini menunjukkan bahwa instrumen keterlaksanaan RPP yang telah dibuat memiliki konsistensi atau keajegan dalam mengukur keterlaksanaan RPP selama pembelajaran. Dengan demikian dapat dikatakan bahwa pembelajaran berlangsung dengan kategori baik. Dapat diartikan pula bahwa RPP yang telah dikembangkan oleh peneliti (yaitu RPP untuk materi pola-pola Hukum
Mendel dengan model inkuiri melalui Drosophila Virtual Labs) dapat diimplementasikan dalam kegiatan belajar mengajar sesungguhnya.

Aktivitas siswa adalah kegiatan yang dilakukan oleh siswa selama proses belajar. Dalam penelitian ini aktivitas siswa dinilai dengan LP aktivitas siswa yang dilakukan oleh 2 orang pengamat. Aktivitas yang diamati adalah 1) mendengarkan dan memperhatikan guru, 2) mengajukan pertanyaan 3) menjawab pertanyaan, 4) berdiskusi, 5) mengerjakan LKS, 6) bekerja dalam kelompok, 7) melakukan simulasi, 8) menganalisa data, 9) membuat kesimpulan, dan 10) mempresentasikan hasil diskusi. Dari Tabel 1 tampak jelas aktivitas yang menonjol adalah diskusi, bekerja dalam kelompok dan melakukan simulasi persilangan. Hal tersebut sangat sesuai dengan tujuan pembelajaran saintifik-inkuiri yang mengharapkan setiap siswa mampu berpikir secara ilmiah, baik secara mandiri maupun kelompok.

\section{Tabel 1. Persentase Aktivitas Siswa Selama Pembelajaran}

\begin{tabular}{|c|l|r|r|r|r|}
\hline No & \multicolumn{1}{|c|}{ Aspek yang diamati } & $\begin{array}{c}\text { Pert. I } \\
(\mathbf{\%})\end{array}$ & $\begin{array}{c}\text { Pert. II } \\
(\mathbf{\%})\end{array}$ & $\begin{array}{c}\text { Pert.III } \\
(\mathbf{\%})\end{array}$ & $\begin{array}{c}\text { Rata- } \\
\text { rata } \\
(\%)\end{array}$ \\
\hline 1. & Mendengarkan/memperhatikan guru & 13.84 & 13.02 & 12.91 & 13.26 \\
\hline 2. & Mengajukan pertanyaan & 7.44 & 7.00 & 6.94 & 7.13 \\
\hline 3. & Menjawab pertanyaan & 3.42 & 3.22 & 3.19 & 3.27 \\
\hline 4. & Berdiskusi & 11.63 & 10.94 & 10.85 & 11.14 \\
\hline 5. & Mengerjakan LKS & 12.40 & 11.67 & 11.57 & 11.88 \\
\hline 6. & Bekerja dalam kelompok & 21.83 & 19.61 & 20.37 & 20.60 \\
\hline 7. & Melakukan simulasi dan pencatatan & 14.72 & 20.59 & 20.42 & 18.58 \\
\hline 8. & Melakukan analisa data & 6.84 & 6.43 & 6.38 & 6.55 \\
\hline 9. & Membuat kesimpulan & 4.08 & 3.89 & 3.86 & 3.94 \\
\hline 10. & Mempresentasikan hasil diskusi & 3.80 & 3.58 & 3.50 & 3.63 \\
\hline Jumlah & & $\mathbf{1 0 0 . 0 0}$ & $\mathbf{1 0 0 . 0 0}$ & $\mathbf{1 0 0 . 0 0}$ & $\mathbf{1 0 0 . 0 0}$ \\
\hline
\end{tabular}

Hasil belajar siswa sesuai dengan tujuan pembelajaran terdiri dari 4 aspek yaitu aspek spiritual, sosial, pengetahuan dan keterampilan. Penilaian dalam aspek spiritual dan aspek sosial dilakukan oleh pengamat melalui lembar penilaian sikap spiritual dan sikap sosial. Sikap-sikap tersebut diukur dengan kategori "Amat Baik" (A), "Baik" (B), "Cukup Baik" (C) dan "Kurang” (D) dengan rubrik yang sudah ditentukan dalam LP. 


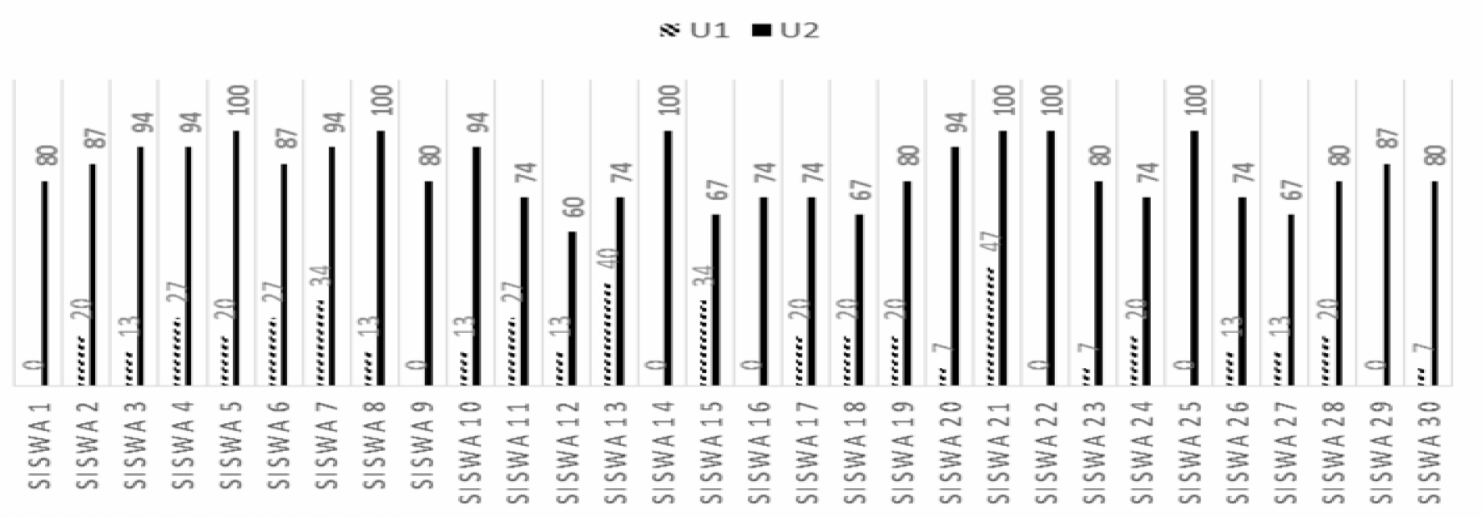

Keterangan : U1 siswa menjawab benar pada pretest; $\mathrm{U} 2=$ siswa menjawab benar pada posttest

Gambar 2. Grafik Hasil Belajar Siswa

Dari penilaian para pengamat, sikap-sikap yang diharapkan muncul dalam pembelajaran memperoleh nilai dengan kriteria "Sangat Baik".

Aspek pengetahuan sebagai hasil belajar kognitif para siswa diukur dengan menggunakan lembar penilaian dalam bentuk soal pilihan ganda sebanyak 15 butir soal yang disesuaikan dengan indikator dan tujuan pem-belajaran. Tes diberikan sebelum proses belajar dan setelah proses belajar sebanyak tiga kali pertemuan. Pada Gambar 2, tampak jelas terjadi kenaikan nilai hasil belajar siswa pada saat pretest dan posttest, dengan rata-rata $\mathrm{N}$ Gain $=0,80$. Artinya, siswa mengalami peningkatan hasil belajar tinggi $(\mathrm{g}>0.7)$.

Berdasarkan hasil penilaian melalui Lembar Penilaian Keterampilan para siswa mendapatkan rata-rata nilai 85 dengan predikat A dengan ketuntasan kelas 93\%, seperti tampak pada Gambar 3. Ketercapaian tersebut disebabkan siswa tidak asing lagi dalam mengoperasikan navigasi komputer, karena mereka menda-patkan pengarahan dan penjelasan prosedur, sehingga siswa langsung dapat mengoperasikan Drosophila Virtual Labs dengan sangat baik.

Gambar 3 Grafik Hasil Nilai Keterampilan

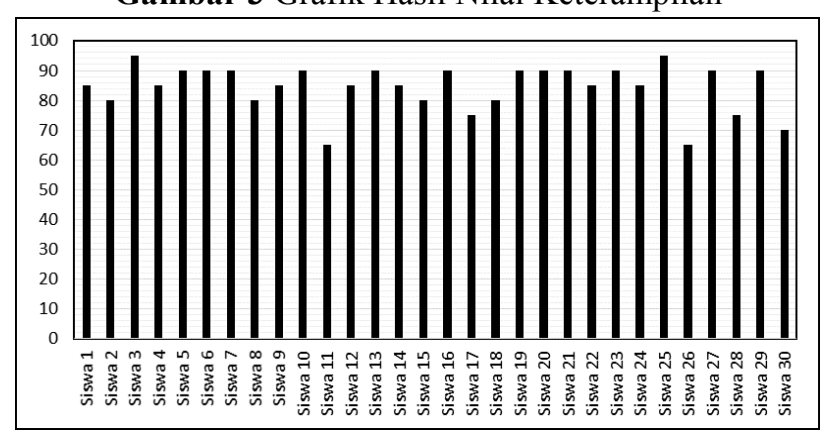

Respon siswa adalah pendapat siswa setelah mengikuti kegiatan belajar mengajar menggunakan model inkuiri dengan media Drosophila Virtual Labs. Rekapitulasi respon siswa berdasarkan uji coba 2 yaitu 30 siswa ditampilkan pada Tabel 2. Berdasarkan Tabel tersebut dapat diketahui bahwa 90\% siswa menganggap proses belajar menjadi menyenangkan dengan model pembelajaran ini dan dapat menghilangkan rasa bosan.

Tabel 2. Respon Siswa

\begin{tabular}{|c|c|c|c|c|c|c|c|c|c|}
\hline \multirow{2}{*}{ No } & \multirow[t]{2}{*}{ Uraian } & \multicolumn{4}{|c|}{ Jumlah Responden } & \multicolumn{4}{|c|}{ Persentase } \\
\hline & & STS & TS & $\mathbf{S}$ & SS & STS & TS & $\mathbf{S}$ & SS \\
\hline & $\begin{array}{l}\text { Pembelajaran Biologi } \\
\text { dengan model inkuiri } \\
\text { melalui Drosophila }\end{array}$ & & & & & & & & \\
\hline 1 & Menyenangkan & 0 & 1 & 21 & 8 & 0 & 3 & 70 & 27 \\
\hline 2 & $\begin{array}{l}\text { Meningkatkan motivasi } \\
\text { belajar }\end{array}$ & 0 & 4 & 24 & 2 & 0 & 13 & 80 & 7 \\
\hline 3 & $\begin{array}{l}\text { Meningkatkan rasa ingin } \\
\text { tahu }\end{array}$ & 0 & 3 & 17 & 10 & 0 & 10 & 57 & 33 \\
\hline 4 & $\begin{array}{l}\text { Meningkatkan } \\
\text { konsentrasi belajar }\end{array}$ & 0 & 1 & 23 & 6 & 0 & 3 & 77 & 20 \\
\hline 5 & $\begin{array}{l}\text { Meningkatkan efetifitas } \\
\text { belajar }\end{array}$ & 0 & 3 & 21 & 6 & 0 & 10 & 70 & 20 \\
\hline 6 & $\begin{array}{l}\text { Lebih mudah memahami } \\
\text { materi }\end{array}$ & 0 & 2 & 20 & 8 & 0 & 7 & 67 & 27 \\
\hline 7 & $\begin{array}{l}\text { BAS menarik untuk } \\
\text { dibaca. }\end{array}$ & 0 & 4 & 24 & 2 & 0 & 13 & 80 & 7 \\
\hline 8 & $\begin{array}{l}\text { Meningkatkan hasil } \\
\text { belajar }\end{array}$ & 0 & 0 & 21 & 9 & 0 & - & 70 & 30 \\
\hline 9 & $\begin{array}{l}\text { Membuat siswa semakin } \\
\text { aktif }\end{array}$ & 0 & 2 & 20 & 8 & 0 & 7 & 67 & 27 \\
\hline 10 & $\begin{array}{l}\text { Guru dan siswa lebih } \\
\text { interaktif }\end{array}$ & 0 & 4 & 22 & 4 & 0 & 13 & 73 & 13 \\
\hline 11 & $\begin{array}{l}\text { Mendorong semangat } \\
\text { berbagi pengetahuan }\end{array}$ & 0 & 4 & 20 & 6 & 0 & 13 & 67 & 20 \\
\hline 12 & $\begin{array}{l}\text { Dapat menjawab } \\
\text { nertanvaan gurl }\end{array}$ & 0 & 1 & 21 & 8 & 0 & 3 & 70 & 27 \\
\hline 13 & $\begin{array}{l}\text { Proses belajar Lebih } \\
\text { menarik dibandingkan } \\
\text { model ceramah }\end{array}$ & 1 & 2 & 15 & 12 & 3 & 7 & 50 & 40 \\
\hline 14 & LKS mudah dipahami & 0 & 2 & 12 & 16 & 0 & 7 & 40 & 53 \\
\hline 15 & $\begin{array}{l}\text { Lebih mampu } \\
\text { menyelesaikan soal-soal }\end{array}$ & 1 & 0 & 21 & 8 & 3 & 0 & 70 & 27 \\
\hline
\end{tabular}

\section{PENUTUP}

\section{Simpulan}

Berdasarkan paparan di atas maka dapat disimpulkan bahwa perangkat pembelajaran yang dikembangkan dengan model inkuiri melalui Drosophila Virtual Laboraory pada materi pokok Pola-pola Hukum Mendel layak digunakan dan dapat meningkatkan hasil belajar siswa. 


\section{Saran}

Berdasarkan pada hasil penelitian yang telah dilakukan, disarankan hal-hal di bawah ini.

1. Sebelum mulai proses pembelajaran dengan Drosophila Virtual Laboratory sebaiknya siswa sudah dikenalkan terlebih dahulu program tersebut untuk melakukan eksplorasi secara mandiri, menganalisis ketersediaan perangkat pendukung berupa laptop, sumber listrik, dan jaringan internet.

2. Agar dilakukan penelitian lanjutan untuk lebih memaksimalkan fasilitas yang disediakan di dalam Drosophila Virtual Laboratory.

3. Drosophila Virtual Laboratory sangat sesuai dengan tuntutan kurikulum 2013 untuk diterapkan pada materi pokok pola-pola Hukum Mendel kelas XII IPA.

\section{DAFTAR PUSTAKA}

Burke, Molly., Center, R., Kelly, L. 2009. Drosophila Handbook: Using Drosophila melanogaster in middle and high school classrooms. (Online), (http://www. bio.uci.edu/academic/grad/GK2/Documents/020709-Burke Drosophila Handbook. pdf. Diakses 1 November 2012.

Cakir,M. and Karaagac, Selen.2012. Virtual Courseware In High School Biology Classroom: Drosophila Lab.

(Online).http://www.academia.edu/556723/virtual_c ourseware_in_high_school_biology_classroom drosophila lāb. Diakses 23 Oktober 2012.

Drosophila Virtual Laboratory. (Online), (http://www. science-course.org/vcise/drosophila). Diakses 20 Ok-tober 2012.

Flowers, Lawrence O. 2011."Investigating the Effectiveness of Virtual Laboratories in an Undergraduate Biology Course." The Journal of Human Resource and Adult Learning Vol.7, Num. 2, December 2011.110.

Hake, Richard R. 1998. "Interactive-engagement versus traditional methods: A six-thousand-student survey of mechanics test data for introductory physics courses". American Journal of Physic., Vol. 66, No. 1, January. 64-74.

Ibrahim, Muslimin. 2005. Asesmen Berkelanjutan. Konsep Dasar, Tahapan Pengembangan dan Contoh. Surabaya: Unesa University Press.

Ibrahim, Muslimin. 2007. "Pembelajaran Inkuiri” Artikel Online http:/ /hermanphysics.blogspot.com/ 2010/12/ pembelajaran-inkuiri.html. Diakses 22 Oktober 2012.

Internet World Statistics. (Online). (http://www.internetworldstats.com/top20.htm. Diakses 23 Oktober 2012.
Joyce, Bruce., and Weil, Marsha. 2003. Model of Teaching. New Delhi: Prentice Hall of India.

Kardi, Soeparman. 2013. Model Pembelajaran Langsung, Inkuiri, Sains Teknologi dan Masyarakat. Surabaya: Program Pascasarjana Universitas Negeri Surabaya.

Pribadi, B.A. 2011. Model Desain Sistem Pembelajaran. Jakarta: Dian Rakyat.

Scheckler, R. 2003."Virtual Labs: a Substitute for Traditional Labs?" The International Journal of Development Biology, 47. 231 - 236.

Tuckman, B., 1978. Conducting Educational Research 2nd Edition. New York : Harcourt Brace Jovanovich.

Undang-Undang Republik Indonesia Nomor 20 tahun 2003 tentang Sistem Pendidikan Nasional. 